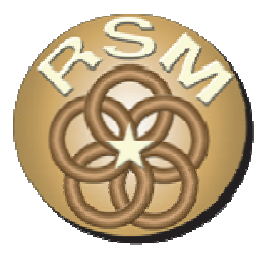

\title{
Evaluating Post-Wildfire Impacts to Flood Risk Management (FRM): Las Conchas Wildfire - New Mexico
}

\author{
by lan E. Floyd, Marielys Ramos-Villanueva, Ronald E. Heath, \\ and Stephen Brown
}

PURPOSE: This U.S. Army Corps of Engineers (USACE) Regional Sediment Management Technical Note (RSM-TN) discusses the impacts of wildfires on USACE Flood Risk Management (FRM) and provides information to evaluate post-fire impacts to USACE missions. The effort was conducted in partnership with the USACE Albuquerque District and was funded through the National RSM and the Flood and Coastal Storm Damage Reduction Research, Development, and Technology Program(s) to understand the impacts of the Las Conchas wildfire on USACE FRM by highlighting the post-fire impacts to the Middle Rio Grande River and Cochiti Reservoir in north-central New Mexico and by presenting approaches to quantify impacts to the USACE mission.

BACKGROUND: The 2011 Las Conchas Wildfire burned more than 600 square kilometers $\left(\mathrm{km}^{2}\right)$ of forested land in the Jemez Mountains (Figure 1), in north central New Mexico. Burn severity was greatest in the mountainous headwaters of some 15 streams that drain directly to the Rio Grande and into the USACE Cochiti Lake (see Figure 1). Since the wildfire, the affected basins have shed sediment at rates far above their historic quantities (Tillery et al. 2012). Based on previous similar events (Cannon et al. 2008), recovery of these watersheds is decades away, creating an ongoing sediment management challenge at Cochiti Lake.

Observational and limited modeling data indicate that dramatic changes in watershed hydrology, geomorphology, and ecology have occurred within the burn area since the event. Calibrated hydrologic model studies at Santa Clara Creek indicated that post-fire peak flow conditions increased by $400 \%$ (e.g., $1 \%$ chance event increased from 140 to 560 cubic meters per second $\left.\left[\mathrm{m}^{3} / \mathrm{s}\right]\right)$. Other tributaries where data have been collected, such as Frijoles Canyon in Bandelier National Monument, show similar ongoing changes in flood hydrology. The amount of future aggradation is unknown. Sediment flushing from Peralta Creek plugged the Rio Grande in September 2013, compromising FRM operations at Cochiti Dam until the plug could be cleared. 


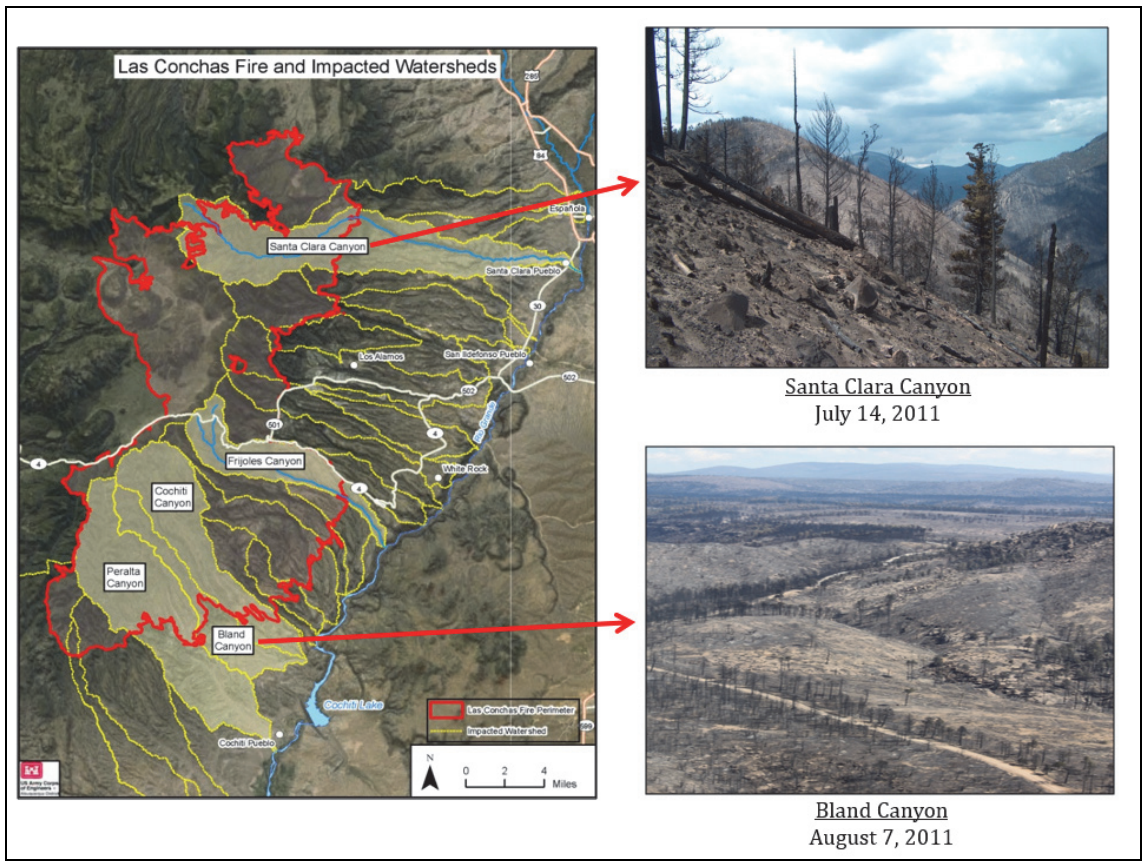

Figure 1. Las Conchas wildfire burn scar and impacted watersheds, withpost-fire photographs of Santa Clara and Bland watersheds.

In addition to the USACE Cochiti Reservoir and Rio Grande Reach, the altered post-Las Conchas fire hydrology directly impacts two federally recognized tribes (Santa Clara Pueblo and Pueblo de Cochiti), Bandelier National Monument, the Valles Caldera National Preserve, and the Los Alamos National Laboratory. A broad coalition of federal and non-federal partners including the U.S. Federal Emergency Management Agency, the U.S. Bureau of Reclamation, and the U.S. Bureau of Indian Affairs have invested in aiding communities to recover from post-fire flooding, in this region. The increased sediment loading has negatively impacted natural resources though significant sediment-laden flood events, destruction of infrastructure (i.e., bridges, culverts, and community water intake structures), and complex reach-specific flood responses on agency lands along the Rio Grande River and at the delta of USACE operated Cochiti Lake (Figure 2). Additionally, the potential long-term sediment impacts to the reservoir and river system have not yet been addressed. At Cochiti Lake, the USACE has a direct need to understand sediment movement downstream of a burn scar since the USACE owns, operates, and manages Cochiti Lake.

The Las Conchas fire is not a unique event. Results from this project will be applied to several other areas affected by other western wildfires (e.g., Waldo Canyon, Colorado; Tres Lagunas, New Mexico; Hayden Pass, Colorado; Carpenter 1, Nevada; and Eagle Creek, Oregon). 


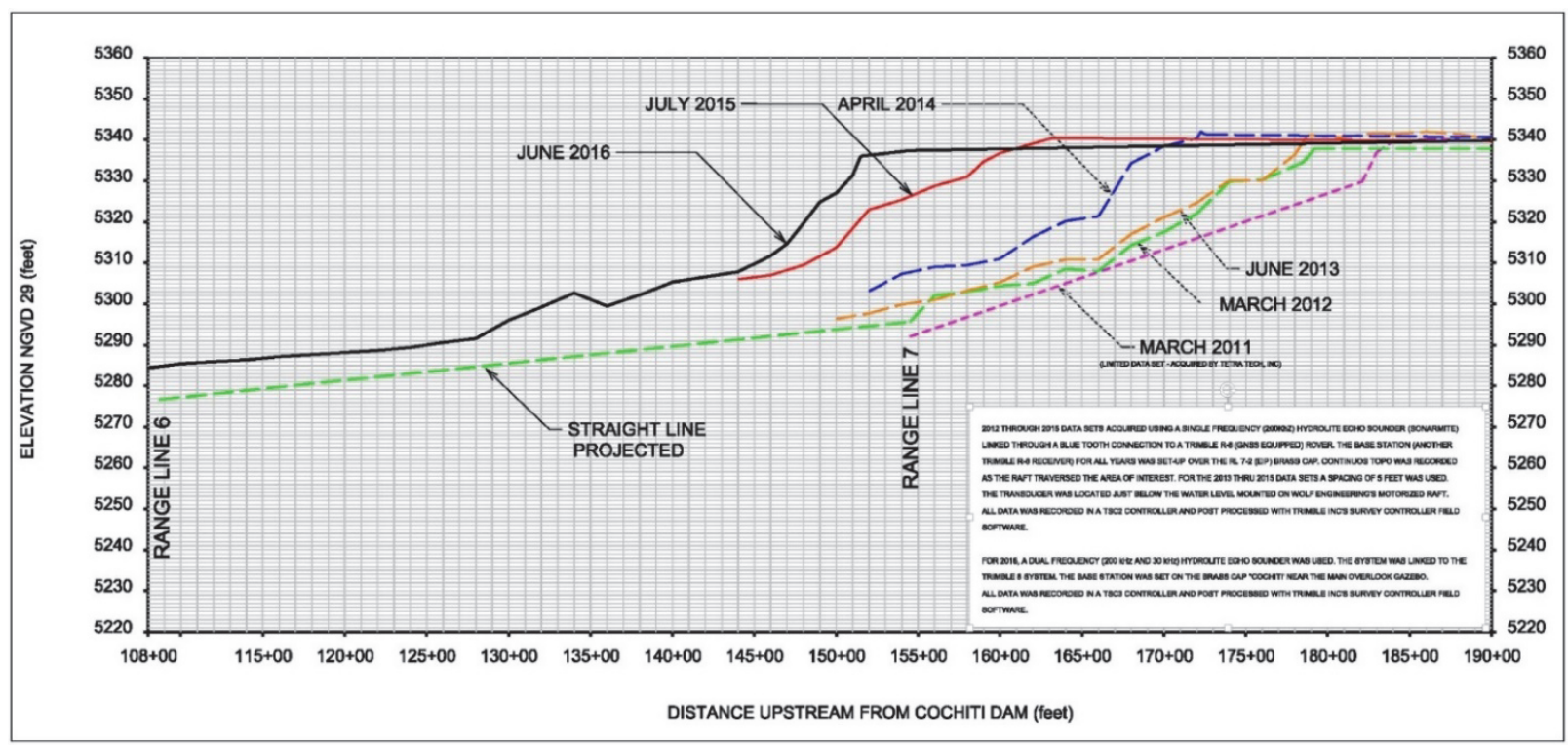

Figure 2. Longitudinal profile at Range Line 7 near Cochiti Reservoir sediment delta, highlighting postfire sediment deposition and aggradation from 2011 to 2016.

A return to pre-fire hydrologic conditions in most of these areas is not anticipated to occur in the near future. An arid climate exacerbated by drought has slowed vegetation re-establishment of the burn scar. Soil fragmentation due to mass wasting processes (i.e., landslides, debris flows, soil sloughing, hyper-concentrated flows, and massive gully formation) are being documented. Sediment delivered to the valley bottoms are subsequently available for sediment remobilization. Both local aggradation near the mass wasting sites as well as broad aggradation throughout the downstream watershed have not yet been systematically quantified. This work will set the stage for developing a national framework for addressing post-fire sediment movement.

CONCEPTS AND TERMINOLOGY: In Newtonian fluids (e.g., water) the viscosity is constant and is independent of shear rate (or strain) with a linear relationship between shear stress and strain (Figure 3). Viscosity is defined as a fluid's ability to resist flow (or deformation) and is commonly expressed as dynamic viscosity. Increasing the sediment solids concentration in relationship to water will lead to non-Newtonian behavior, which results in nonlinear relationships in viscosity and deformation. 


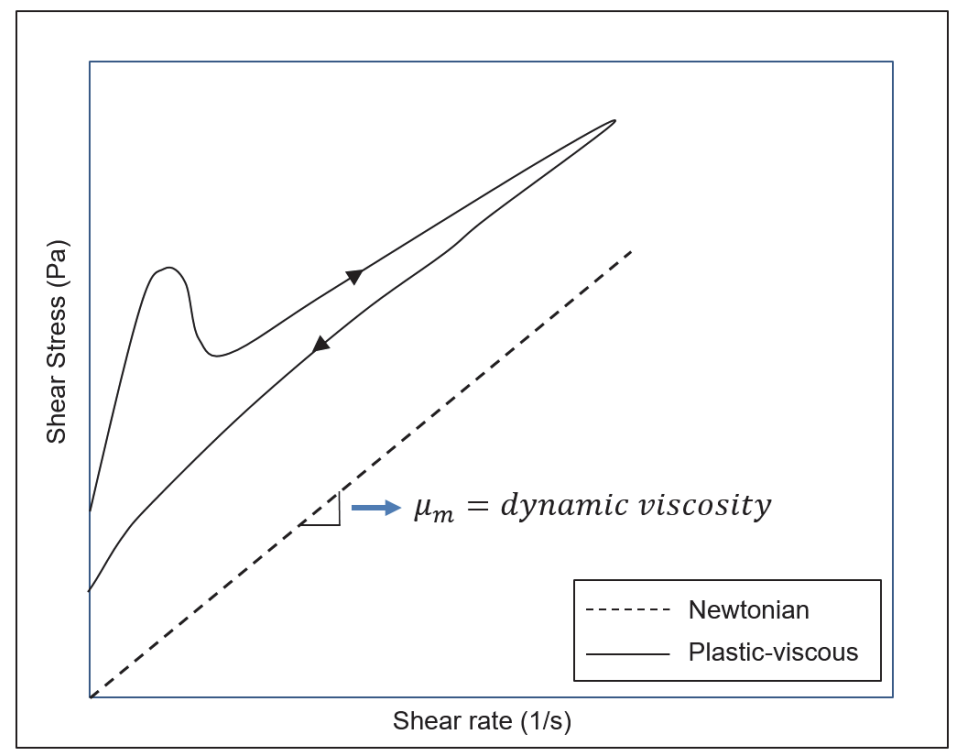

Figure 3. Idealized rheogram describing Newtonian and non-Newtonian fluid behavior.

Mixtures containing sufficient cohesive sediment (approximately $5 \%$ to $10 \%$ by volume) require a minimal stress for the mixture to deform and/or flow. The effects of non-Newtonian flow begin when sediment concentrations reach a volume fraction of approximately 0.05 and terminates near the maximum specific volume sediment concentration $\left(\mathrm{C}_{\max }\right)$ of approximately 0.615 for ideal homogeneous size spheres (Bagnold 1954; Julien 2010). Post-fire floods represent geophysical flows that are unsteady gravity driven events involving complex mixtures of sediment, water, and entrained material (e.g., organics, woody debris, and unconsolidated substrate) and are commonly modeled using shallow-water equations with non-Newtonian approximations (e.g., Iverson 1997; Jin and Fread 1997; Imran et al. 2001). These types of flows are dominantly influenced by grain-size distribution, sediment concentration, and flow stress state. The stress state is typically used to describe the dominant form of physical and numerical dissipation within the fluid flow. These stress states generally represent the following processes: cohesion, internal friction between fluid and sediment, turbulence, and the inertial impact between particles. A variety of methods are appropriate for dynamically predicting debris flow events and are commonly grouped into the following categories:

- Linear (e.g., Bingham 1922) and non-linear viscoplastic models (e.g., Jin and Fread 1997; Imran et al. 2001)

○ Most commonly used to describe the rheology of laminar mud flows.

$\circ$ Bingham rheology model is most mature method, with applications quantifying fluid mud in estuaries and density currents in reservoirs.

- $\quad$ Dispersive fluid models (e.g., Bagnold 1954; Takahashi 1978)

- Describes the particle-to-particle interaction between granular-clastic (i.e., silt, sand, gravel) particles, commonly applied to sediment-water mixtures containing mostly sand and gravel with lower quantities of fine sediment $(\leq 5 \%-10 \%$ by volume).

- Dispersive-turbulent stress models (e.g., O’Brien et al. 1993) 
- Incorporates the dispersive model with a turbulent stress model to describe the mechanics of particle-to-particle interactions within a clay, silt, and organic matrix. Commonly applied to sediment mixtures containing cohesive sediment in quantities greater than $10 \%$ by volume.

- Coulomb-based frictional models (e.g., Iverson 1997; Denlinger and Iverson 2001).

- Commonly used to describe the non-Newtonian mechanics of poorly sorted (i.e., wide range of sediment grain sizes) heterogeneous clastic debris flows.

Many different definitions have been used within the literature to describe bulk properties of sediments-laden water. These bulk properties include, but are not limited to, volume concentration, packing fraction/density, mass concentration, porosity, bulk density, relative moisture content, water content, etc. A selection of common physical properties and relationships of water-sediment mixtures is provided in Table 1.

\section{Table 1. Physical properties and relationships of non-Newtonian water-sediment mixtures.}

\begin{tabular}{|l||c||c||c|}
\hline \hline Physical Properties & Symbol & Units & Relationships* $^{*}$ \\
\hline \hline Sediment Concentration (by volume) & $C_{v}$ & Dimensionless (-) & $\mathrm{C}_{\mathrm{v}}=1-\mathrm{p}_{\mathrm{o}}$ \\
\hline Mass Density of Sediment Mixture & $\rho_{m}$ & $\mathrm{~kg} / \mathrm{m}^{3}$ & $\rho_{\mathrm{m}}=\rho+\left(\rho_{\mathrm{s}}-\rho\right) \mathrm{C}_{\mathrm{v}}$ \\
\hline Mixture Void Ratio & $e$ & Dimensionless (-) & $\mathrm{e}=\frac{1-\mathrm{C}_{\mathrm{v}}}{\mathrm{C}_{\mathrm{v}}}$ \\
\hline Dry Specific Mass of Mixture & $\rho_{m d}$ & $\mathrm{~kg} / \mathrm{m}^{3}$ & $\rho_{\mathrm{md}}=\rho_{\mathrm{s}} \mathrm{C}_{\mathrm{v}}$ \\
\hline Dynamic Viscosity of Mixture & $\mu_{m}$ & $\mathrm{~Pa} \mathrm{~s}$ & $\mu_{\mathrm{m}}=\mu_{\mathrm{w}}\left(1+2.5 \mathrm{C}_{\mathrm{v}}\right)$ \\
\hline Kinematic Viscosity of Mixture & $\gamma_{m}$ & $\mathrm{~m} / \mathrm{s}$ & $\gamma_{\mathrm{m}}=\frac{\mu_{\mathrm{m}}}{\rho_{\mathrm{m}}}$ \\
\hline
\end{tabular}

* where $p_{0}$ is porosity (dimensionless), $\rho$ is the density of water (kilograms per cubic meter $\left[\mathrm{kg} / \mathrm{m}^{3}\right]$ ), $\rho_{s}$ is sediment particle density $\left(\mathrm{kg} / \mathrm{m}^{3}\right), \mu_{w}$ is the dynamic viscosity of water (Pascal seconds [Pa s]), and $\gamma_{m}$ is the kinematic viscosity of the sediment mixture $\left(\mathrm{m}^{2} / \mathrm{s}\right)$.

POST-FIRE HYDROLOGY AND HYDRAULICS: Large wildfires, specifically in geomorphically sensitive arid regions, represent a significant perturbation (or shock) to the natural systems and dramatically alter the geomorphology, hydrology, and sedimentation regimes. Geomorphic sensitivity describes systems that cannot handle large changes typically due to slow growth and implies a conditional instability in an environment, with the possibility of rapid and permanent changes, due to perturbations like wildfires in arid or semi-arid mountainous regions (Phillips 1999; Thomas 2001). Wildfires produce complex and varying spatial effects to a given watershed and impact hydrology by removing the vegetation inception 
canopy, covering the land surface through the production of ash and burned material, reducing organic binding materials in soils, development of hydrophobic (or water repellant soils), and altering the physical transport properties of soils and sediments (Certini 2005; Moody et al. 2009; Ebel et al. 2012). Effects on the hydrology include changes to evapotranspiration and surface and substrate moisture storage and flows, decreased watershed lag time, higher peak flows, and reduced interception and reduce infiltration capacity (Neary et al. 2003; WEST 2011).

In the years following a wildfire, ecotone shifts, gully formation, and channel incision alter the hydrologic system response, resulting in dramatic changes in hydraulic and sediment impacts down-system. In most of the western arid and semi-arid mountainous United States, post-wildfire recovery can take decades, posing potential long-term operation and management concerns for USACE and other federal, state, and local agencies. Since burned regions lack vegetation to intercept and slow surface runoff produced by rainfall events, post-fire peak flows in those areas have reached all-time highs, with documented hyper-concentrated flows (Tillery et al. 2012; Rio Grande Water Fund 2015) (Figure 4). These flows often carry large boulders, trees, and even cars because of the high density and tremendous momentum of the flowing sediment laden flows.

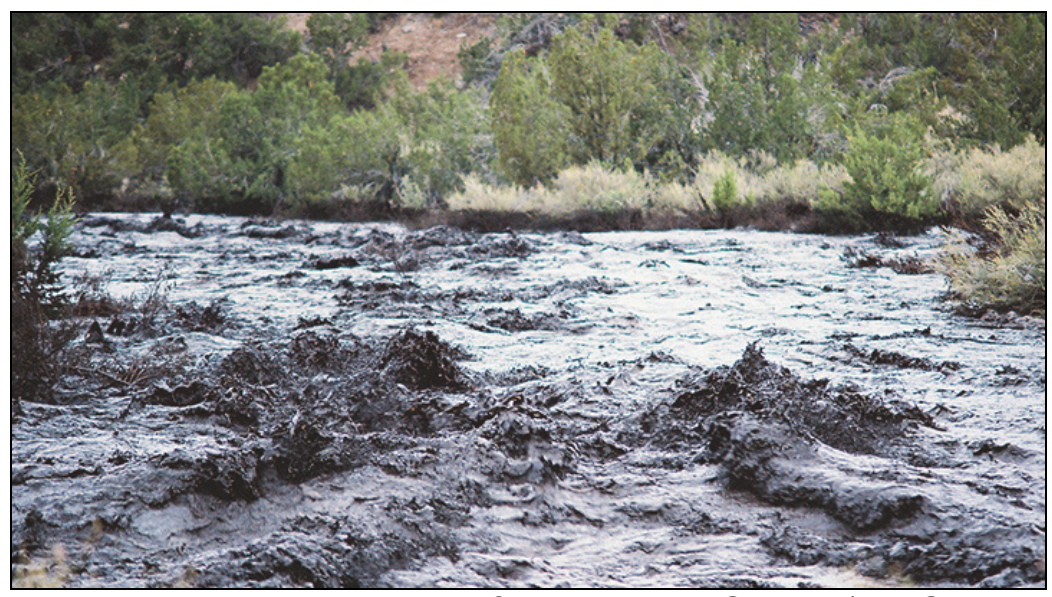

Figure 4. Hyper-concentrated flow in the Rio Grande (Rio Grande Water Fund 2015).

Post-fire flooding impacts are commonly defined by the given event probability, magnitude, and intensity. Probability is the likelihood that an event will occur in the future, while frequency represents how often a given event occurs (inverse of the return period). The probability or likelihood of a debris flow occurring can be estimated from Cannon et al. (2010), defined as

$$
\begin{gathered}
\mathrm{P}=\frac{\mathrm{e}^{\mathrm{x}}}{\left(1-\mathrm{e}^{\mathrm{x}}\right)} \\
\mathrm{x}=-0.7+0.03(\mathrm{SG})-1.6(\mathrm{R})+0.06\left(\mathrm{~A}_{\mathrm{B}}\right)+0.07(\mathrm{I})+0.2(\mathrm{C})-0.4(\mathrm{LL})
\end{gathered}
$$

where $\mathrm{SG}$ is the percent of the drainage basin area with slope greater than or equal to $30 \%, \mathrm{R}$ is the watershed ruggedness (or the change in drainage basin elevation divided by the square root of the drainage basin area $\left(\mathrm{m} \mathrm{m}^{-1 / 2}\right), \mathrm{A}_{\mathrm{B}}$ is the percentage of drainage basin area burned at moderate and high severity (\%), I is the average storm intensity (millimeters per hour $\left[\mathrm{mm} \mathrm{hr}^{-1}\right]$ ), 
$\mathrm{C}$ is the percent clay content of the soil (\%), and LL is the liquid limit of the soil (\%). The postfire flood event magnitude is commonly expressed in terms of total flow volume, peak discharge, or area inundated. The initiation of post-fire debris flood events is commonly attributed to two main processes: (1) runoff-driven erosion by surface flows and (2) infiltration triggered failures and movement of distinctive landslide mass (Cannon and Gartner 2005). Flood events generated through runoff-based processes are commonly the result of high-intensity, short-duration storms (Cannon and Gartner 2005). As such, a precipitation threshold condition exists that describes the onset of debris flow generation. Cannon et al. (2008) defined the threshold rainfall intensity duration given in the following form:

$$
\mathrm{I}=\mathrm{aD}^{-\mathrm{b}}
$$

where $\mathrm{D}$ is the duration (hr) of rainfall of intensity (I) $(\mathrm{mm} / \mathrm{hr}), a$ is site-specific empirical coefficient (ranges between 6.5 and 14), and $b$ is a site-specific empirical exponent (ranges between -0.4 and -0.7) (Cannon et al. 2008). This threshold is a useful metric for issuing warnings and emergency response in the western United States and is appropriate in steep, recently burned watersheds underlain by easily erodible soils and sediments with thin deposits of colluvium and alluvium. Colluvium is defined as loose, heterogeneous angular sediments deposited at the base of a steep hill slope or cliff in the upper watershed. Alluvium is defined as homogeneous previously eroded and reworked sediments like clays, silts, and sands deposited in lower energy floodplain reaches within a watershed. Cannon et al. (2010) highlights an empirical debris-flow volume model used to estimate the mean volume of material deposited by a debris flow at the outlet of a recently burned basin in the United States intermountain west, defined as

$$
\ln \mathrm{V}=7.2+0.6(\ln \mathrm{SG})+0.7\left(\mathrm{~A}_{\mathrm{B}}\right)^{\frac{1}{2}}+0.2(\mathrm{~T})^{\frac{1}{2}}+0.3
$$

where $\mathrm{V}$ is the deposited volume $\left(\mathrm{m}^{3}\right)$ and $\mathrm{T}$ is the total storm rainfall $(\mathrm{mm})$. Additional relationships to estimate debris flow volume and peak discharge have been documented in the literature (e.g., Cannon et al. 2001; Cannon and Gartner 2005; Cannon et al. 2010) with sitespecific coefficients and range of application.

An emergency assessment example is provided to demonstrate computation of debris flow frequency and volume for a given rainfall event. The example focuses on five watersheds immediately upstream of Cochiti Reservoir (Figure 5). 


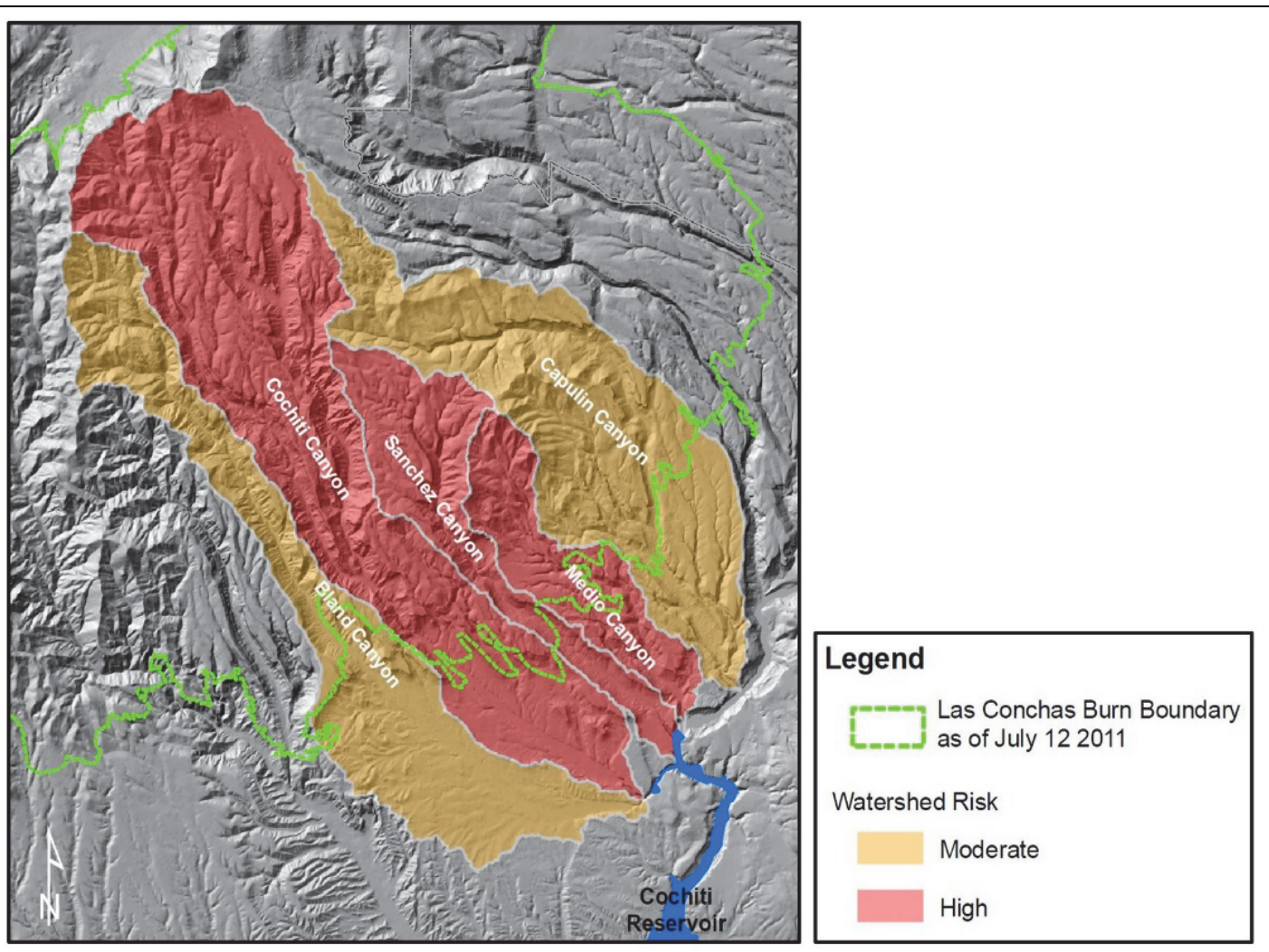

Figure 5. Post-fire emergency assessment and burn severity for five impacted water-sheds upstream of Cochiti Reservoir.

The probability of debris-flow and volume were computed using the approach developed by Cannon et al. (2010) provided above in Equations (1), (2), and (4) for a 5-year return period rainfall event. The computed probability of a debris flow occurring and the volume of the debris flow for the five watersheds is provided in Table 2.

\begin{tabular}{|c|c|c|}
\hline $\begin{array}{l}\text { Table 2. Computed debris flow probability and volume of a 5-year } \\
\text { rainfall event for five impacted watersheds. }\end{array}$ \\
\hline \hline \multicolumn{2}{|c|}{ Computed Probability and Volume for a 5-Year Rainfall Event } \\
\hline Watershed Name & Computed Probability (\%) & Computed Volume km $\mathbf{~}^{\mathbf{}}$ \\
\hline \hline Bland Canyon & 47 & 0.008 \\
\hline Cochiti Canyon & 94 & 0.054 \\
\hline Sanchez Canyon & 91 & 0.042 \\
\hline Medio Canyon & 76 & 0.018 \\
\hline Capulin Canyon & 75 & 0.02 \\
\hline
\end{tabular}


Cannon et al. (2004) successfully defined a relationship between peak discharge, burned area, average watershed gradient, and precipitation intensity, estimated by

$$
Q_{p}=171+0.552 \theta+2.84 \log A_{B}+3.6 I
$$

where $Q_{p}$ is the debris-flow peak discharge $\left(\mathrm{m}^{3} \mathrm{~s}^{-1}\right)$, and $\theta$ is the average basin gradient (\%). It is important to recognize that most empirical-based models are restricted to use in watersheds with comparable physical and ecological characteristics similar to the basin from which the model was derived. In addition to empirical-based approaches, analytical bulking models can be useful when coupled with a hydrologic model like the USACE Hydrologic Engineering Center Hydrological Modeling System. Richardson et al. (2001) defines bulking as increasing the total water discharge to account for high sediment concentrations within the flow, due to sediment entrainment (WEST 2011). A bulking factor (BF) is commonly applied to the peak water discharge to estimate the total (bulked) peak discharge and serves as a safety factor in water resource design (Hamilton and Fan 1996). In an undeveloped watershed with sufficient sediment storage, the bulked peak discharge is defined as

$$
\mathrm{Q}_{\mathrm{B}}=\mathrm{Q}_{\mathrm{w}}+\mathrm{Q}_{\mathrm{s}}
$$

where $Q_{B}$ is the bulked peak discharge $\left(\mathrm{m}^{3} \mathrm{~s}^{-1}\right), Q_{w}$ is the clear-water discharge $\left(\mathrm{m}^{3} \mathrm{~s}^{-1}\right)$, and $Q_{s}$ is the volumetric sediment discharge $\left(\mathrm{m}^{3} \mathrm{~s}^{-1}\right)$. The BF is the ratio of the bulked discharge to the clear-water discharge:

$$
\mathrm{BF}=\frac{\left(\mathrm{Q}_{\mathrm{w}}+\mathrm{Q}_{\mathrm{s}}\right)}{\mathrm{Q}_{\mathrm{w}}}
$$

Using this definition, the bulked peak discharge may be defined as

$$
\mathrm{Q}_{\mathrm{B}}=\mathrm{BF}^{*} \mathrm{Q}_{\mathrm{w}}
$$

The BF may also be computed based on the concentration of sediment in the flow as

$$
\mathrm{BF}=\frac{1}{1-\frac{\mathrm{C}_{\mathrm{v}}}{100}}
$$

Common intensity parameters useful in predicting post-fire flood events include the depth and velocity of flow, total runout length of debris flow, and impact forces on in-channel structures. Julien and Paris (2010) provide relationships describing mean velocity of mudflows, hyperconcentrated flows, and debris flows developed from 350 field and laboratory datasets. They derive three approaches to estimate velocity, parameterized from field and laboratory data using Darcy-Weisbach and Manning-Strickler flow resistance relationships (Table 3). 


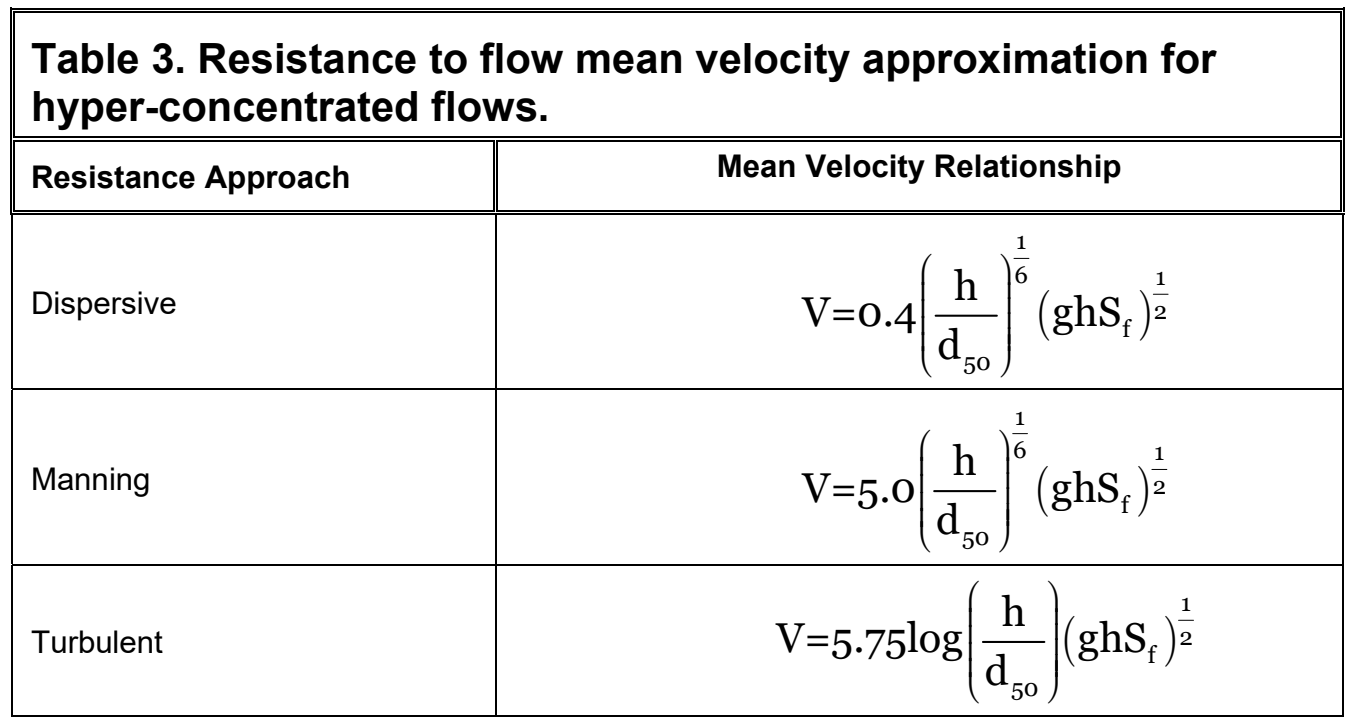

where $V$ is mean velocity $\left(\mathrm{m} \mathrm{s}^{-1}\right), h$ is flow depth $(\mathrm{m}), d_{50}$ is the median grain diameter $(\mathrm{m}), \mathrm{g}$ is the acceleration due to gravity $\left(\mathrm{m} \mathrm{s}^{-2}\right), S_{f}$ is the friction slope $\left(\mathrm{m} \mathrm{m}^{-1}\right), \tau$ is the shear stress

(Pa) $\left(=\rho_{m} g h S\right)$, and $\tau_{y}$ is the non-Newtonian slurry dynamic yield strength $(\mathrm{Pa})$.

Additionally, post-fire flood events exhibit other unique non-Newtonian properties that warrant discussion and definition, including lower settling velocity (deposition) and higher boundary shear stress (erosion). To understand the impacts on particle settling, visualize the differences in fall velocity of a marble dropped into suspensions of clear water versus honey. As can be imagined, the spheres dropped in honey will settle much more slowly compared to spheres dropped in water. In non-Newtonian mechanics, this phenomena is referred to as hindered settling. When sediment slurry volumetric concentration increase above 0.05 , the sediment particles start to hinder each other, resulting in decreased particle settling velocity compared to the same particle in clear water (Tomkins et al. 2005; Floyd et al. 2016). A variety of explanations have been proposed to explain the physical processes responsible for hindered settling. A complete review is outside the scope of this document, but additional background and theory on hindered settling can be found in Cheng (1997), Winterwerp and Van Kesteren (2004), and Cuthbertson et al. (2008), among others. Most hindered settling expressions for noncohesive and cohesive sediments are based on the formulation by Richardson and Zaki (1954) where return flow, wake formation, and buoyancy are accounted for empirically, and defined as

$$
\mathrm{w}_{\mathrm{s}}=\mathrm{w}\left(1-\mathrm{C}_{\mathrm{v}}\right)^{\mathrm{m}}
$$

where $w_{s}$ is settling velocity $\left(\mathrm{m} \mathrm{s}^{-1}\right), w$ is settling velocity of single particles in still water $\left(\mathrm{m} \mathrm{s}^{-1}\right)$, $C_{v}$ is volumetric concentration of primary particles within a sediment mixture (dimensionless), and $m$ is an empirical coefficient (dimensionless). The effects of hindered settling are commonly observed in post-fire floods via very large boulders being transported considerable distances from the source location.

Boundary (or bed) shear stress is another key parameter when estimating erosion and deposition potential. The boundary shear stress is a function of gravity, flow depth, sediment mixture-slurry density, and channel slope, defined as 


$$
\tau_{\mathrm{o}}=\rho_{\mathrm{m}} \mathrm{ghS}_{\mathrm{f}}
$$

Slurry mass densities in natural non-Newtonian flows can be considerably larger than in Newtonian clear water open channel flows, thereby significantly increasing the bed shear stress and potential for sediment entrainment. A practical application is sizing rip rap for post-wildfire mitigation and management infrastructure. For clear water flows, the boundary shear stress is estimated using the density of the fluid, which is approximately $1,000 \mathrm{~kg} \mathrm{~m}^{-3}$. In most post-fire floods the sediment mass density is commonly approximately $1,500 \mathrm{~kg} \mathrm{~m}^{-3}$ resulting in a $40 \%$ increase in boundary shear stress Equation (11). This also results in significant increases in sediment entrainment potential and channel scour.

SUMMARY AND CONCLUSION: Watersheds within western burn areas are now at significant risk of damage from post-wildfire sedimentation hazards such as those associated with debris flows and mud flows. Surface runoff and debris flow processes in burned watersheds are complex, often non-linear processes. Wildfires remove vegetation and create hydrophobic soils, resulting in increased discharge and sediment transport. Post-fire hydrology and debris flow models can be useful tools for assessing wildfire impacts by estimating post-fire flow and debris flow.

Newly developed modeling capabilities can provide critical numerical modeling boundary conditions to conduct robust river and reservoir sediment analyses. In most of the western United States, post-wildfire recovery can take decades, posing potential long-term operations and management concerns for USACE and other federal, state, and local agencies. Future efforts will continue to focus on enhancing modeling capabilities to quantify post-wildfire impacts on hydrologic and hydraulic response, geomorphic evolution, and sedimentation processes. This research will generate studies related to the following:

- Better understanding of the longer term geomorphic impacts and subsequence recovery processes in post-fire environments

- Hydrological physical processes, empirical approaches, and numerical modeling

- Hydraulics and sediment transport physical processes and numerical modeling.

ADDITIONAL INFORMATION: This USACE Regional Sediment Management Technical Note (RSM-TN) was prepared by Ian E. Floyd, Marielys Ramos-Villanueva, and Ronald E. Heath, U.S. Army Engineer Research and Development Center (ERDC), Vicksburg, MS; and Stephen Brown, U.S. Army Engineer District, Albuquerque (SPA). Funding for this study and RSM-TN was provided by the USACE National Regional Sediment Management (RSM) and the Flood and Coastal Storm Damage Reduction (FCSDR) Research Program(s) to assist users in identifying post-wildfire impacts and development of strategies to manage sedimentation. Additional information pertaining to the National RSM Program can be found at the RSM website http://rsm.usace.army.mil.

Questions regarding this RSM-TN may be addressed to the following:

Ian E. Floyd

Katherine E. Brutsché

(USACE National RSM Program Manager)
Ian.E.Floyd@usace.army.mil

Katherine.E.Brutsche@usace.army.mil 
This ERDC/TN RSM-19-4 should be cited as follows:

Floyd, I. E., M. Ramos-Villanueva, R. E. Heath, and S. W. Brown. 2019. Evaluating Post-Wildfire Impacts to Flood Risk Management (FRM): Las Conchas Wildfire - New Mexico. ERDC/TN RSM-19-4. Vicksburg, MS: U.S. Army Engineer Research and Development Center. http://dx.doi.org/10.21079/11681/32910

\section{REFERENCES}

Bagnold, R. A. 1954. Experiments on gravity-free dispersion of a large solid sphere in a Newtonian fluid under shear. In Proceedings of the Royal Society of London. Series A.

Bingham, E. C. 1922. Fluidity and Plasticity. Vol. 2. New York: McGraw-Hill.

Cannon, S. H., E. R. Bigio, and E. Mine. 2001. A process for fire-related debris-flow initiation, Cerro Grande Fire, New Mexico. Hydrological Processes 15: 3011-3012.

Cannon, S. H., J. E. Gartner, M. G. Rupert, and J. A. Michael. 2004. Emergency Assessment of DebrisFlow Hazards from Basins Burned by the Cedar and Paradise Fires of 2003, Southern California. USGS Open-File Report 04-1011. Reston, VA: U.S. Geological Survey.

Cannon, S. H., and J. E. Gartner. 2005. Wildfire-related debris flow from a hazards perspective. DebrisFlow Hazards and Related Phenomena. Chapter 15. Edited by M. Jakob and O. Hungr. SpringerPraxis Books in Geophysical Sciences.

Cannon, S. H., J. E. Gartner, R. C. Wilson, J. C. Bowers, and J. L. Laber. 2008. Storm rainfall conditions for floods and debris flows from recently burned areas in southwestern Colorado and southern California. Geomorphology 96: 250-268.

Cannon, S. H., J. E. Gartner, M. G. Rupert, J. A. Michael, A. H. Rea, and C. Parrett. 2010. Predicting the probability and volume of post-wildfire debris flows in the intermountain western United States. Geological Society of America. Bulletin 122 (1/2): 127-144.

Certini, G. 2005. Effects of fire on properties of forest soils: A review. Oecologia 143(1): 1-10.

Cheng, N.S., 1997. Effect of concentration on settling velocity of sediment particles. Journal of Hydraulic Engineering 123(8): 728-731.

Cuthbertson, A., P. Dong, S. King, and P. Davies. 2008. Hindered settling velocity of cohesive/noncohesive sediment mixtures. Coastal Engineering 55(12): 1197-1208.

Denlinger, R. P., and R. M. Iverson. 2001. Flow of variably fluidized granular masses across threedimensional terrain: Part 2; Numerical predictions and experimental tests. Journal of Geophysics Research 106(B1): 553-566.

Ebel, B. A., J. A. Moody, and D. A. Martin. 2012. Hydrologic conditions controlling runoff generation immediately after wildfire. Water Resources Research 48: 1-13.

Floyd, I. E., S. J. Smith, S. H. Scott, and G. L. Brown. 2016. Flocculation and Settling Velocity Estimates for Reservoir Sedimentation Analysis. ERDC/CHL CHETN-XIV-46. Vicksburg, MS: U.S. Army Engineer Research and Development Center.

Hamilton, D. L., and S. S. Fan. 1996. Reliability of sediment transport modeling for shallow flow on initially dry areas. In Proceeding of the Sixth Federal Interagency Sedimentation Conference. Las Vegas, NV.

Imran, J., G. Parker, J. Locat, and H. Lee. 2001. 1D numerical model of muddy subaqueous and subaerial debris flows. Journal of Hydraulic Engineering 127: 959-968. 
Iverson, R. M. 1997. The physics of debris-flows. Reviews of Geophysics, American Geophysical Union 35(3): 245-296.

Jin, M., and D. L. Fread. 1999. 1D Modeling of Mud/Debris unsteady flows. Journal of Hydraulic Engineering 125(8): 827-834.

Julien, P. Y. 2010. Erosion and Sedimentation. $2^{\text {nd }}$ edition. Cambridge, UK: Cambridge University Press.

Julien, P. Y., and A. Paris. 2010. Mean velocity of mudflows and debris flows. Journal of Hydraulic Engineering 136(9): 676-679.

Moody, J. A., D. A. Kinner, and X. Ubeda. 2009. Linking hydraulic properties of fire affected soils to infiltration and water repellency. Journal of Hydrology 379(3-4): 291-303.

Neary, D. G., G. J. Gottfried, and P. F. Folliott. 2003. Post-wildfire watershed flood responses. $22^{\text {nd }}$ International Wildland Fire Ecology and Fire Management Congress.

O’Brien, J. S., P. Y. Julien, and W. T. Fullerton. 1993. Two dimensional water flood and mudflow simulation. Journal of Hydraulic Engineering 119(2): 244-261.

Philips, J. D. 1999. Earth Surface Systems. Blackwell, Oxford.

Richardson, J. F., and W. N. Zaki, 1954. The sedimentation of a suspension of uniform spheres under conditions of viscous flow. Chemical Engineering Science 3(2): 65-73.

Richardson, E. V., D. B. Simon, and P. F. Lagasse. 2001. River Engineering for Highway Encroachments - Highways in the River Environment. Hydraulic Design Series Number 6. Publication No. FHWA NHI 01-004. Prepared for Federal Highway Administration by Ayres Associates.

Rio Grande Water Fund. 2015. The Nature Conservancy in New Mexico. The Nature Conservancy. 6 July 2015. https://www.nature.org/en-us/about-us/where-we-work/united-states/new-mexico/stories-innew-mexico/new-mexico-rio-grande-water-fund/

Takahashi, T. 1978. Mechanical characteristics of debris-flows. Journal of the Hydraulics Division 104(8): 1153-1169.

Thomas, M. F. 2001. Landscape sensitivity in time and space - an introduction. Catena 42(2-4): 83-98.

Tillery, A. C., M. J. Darr, S. H. Cannon, and J. A. Michael, 2012. Post-Wildfire Preliminary Debris Flow Hazard Assessment for the Area Burned by the 2011 Las Conchas Fire in North-Central New Mexico. USGS Open-File Report 2012-1188. Reston, VA: U.S. Geological Survey.

Tomkins, M. R., T. E. Baldock, and P. Nielson. 2005. Hindered settling of sand grains. Sedimentology 52(6): 1425-1432.

WEST Consultants, Inc. 2011. Sediment/Debris Bulking Factors and Post-Fire Hydrology for Ventura County: Final Report. Prepared for Ventura County Watershed Protection District, Ventura, CA.

Winterwerp, J. C., and W. G. M. Van Kesteren. 2004. Introduction to the physics of cohesive sediment in the marine environment. Developments in Sedimentology 56, Elsevier.

NOTE: The contents of this technical note are not to be used for advertising, publication, or promotional purposes. Citation of trade names does not constitute an official endorsement or approval of the use of such products. 